EESTI NSV TEADUSTE AKADEEMIA TOIMETISED. XVIII KÖIDE

KEEMIA * GEOLOOGIA. 1969, Nr. 2

ИЗВЕСТИЯ АКАДЕМИИ НАУК ЭСТОНСКОИ ССР. ТОМ ХVIII

ХИМИЯ * ГЕОЛОГИЯ. 1969, № 2

A. РАУКАС, Э. РЯХНИ

\title{
О ГЕОЛОГИЧЕСКОМ РАЗВИТИИ ВПАДИНЫ И БАССЕЙНОВ ЧУДСКОГО И ПСКОВСКОГО ОЗЕР
}

Геологическое строение и развитие впадины Чудского и Псковского озер и эволюция распространявшихся в ней водоемов уже издавна привлекали внимание исследователей. Тем не менее многие вопросы в этой области еще не решены и, по-видимому, еще долгие годы будут служить объектом ожиеленных дискуссий. Настоящая статья является некоторым вкладом в решение этой проблемы.

Впадина Чудского и Псковского озер образовалась, вероятно, уже в доледниковое время (Zur Mühlen, 1918; Mieler, 1926; Orviku, 1959 и др.). Она сформировалась в основном в полосе песчано-глинистых отложений среднего и верхнего девона, которые относительно легко подвергались разрушению. Опираясь на несогласное залегание отложений наровского горизонта среднего девона на отложениях ордовика, К. Каяк (Кајак, 1964) предполагает, что по меньшей мере северная часть впадины Чудского озера начала формироваться уже до наровского времени, причем для образования Лужско-Нарвской и Оямааской низменностей, видимо, существовали предпосылки тектонического характера в виде зон тектонических нарушений северо-восточного и северо-западного направлений. Образование Псковской низины также связано с активной денудацией в зоне повышенной трещиноватости пород (Исаченков, 1966). Не исключено, что подразделение впадины Чудского и ПІсковского озер на две полуизолированные части может быть в какой-то степени предопределено локальными депрессиями (Исаченков, 1966), хотя для подтверждения этого предположения пока геологических данных не имеется.

Судя по геологическому строению Саадъярвского друмлинового поля, Отепяской и Хааньяской возвышєнностей (Каяк, 1965а, б), описываемая впадина в плейстоцене по крайней мере четырехкратно покрывалась щитом материкового льда, который продвигался главным образом с севера на юг и с северо-запада на юго-восток, что отражается и в современной морфологии впадины. Учитывая последнее обстоятельство, некоторые исследователи (Grewingk, 1879; Hausen, 1913; Tammekann, 1928) считали, что впадина Чудского и Псковского озер образовалась экзарационным путем.

Каким был рельеф рассматриваемой озерной впадины до материковых оледенений и во время отдельных межледниковий, судить довольно трудно. Принимая во внимание значительную глубину (местами до 60 - 80 и более метров) погребенных или частично погребенных долин в пределах впадины и на соседних территориях, состав отложений, слагающих долины, и низкое положение базиса эрозии долин, можно предположить, что по крайней мере в доледниковое время, но, вероятно, и. 
на протяжении межледниковий впадина Чудско-Псковского водоема была освоена речной сетью с преобладающим направлением течения рек на запад и юго-запад (Tammekann, 1928 и др.).

В ходе деградации ледников последнего оледенения в пределах впадины Чудского и Псковского озер сформировались краевые ледниковые образования двух стадий (или фаз), которые в Псковской и Ленинградской областях именуются как лужская и невская (Алейников, 1957, 1960; Вигдорчик и др., 1962 и др.), а в Эстонии как хааньяская и пандивереская (Раукас, 1963 и др.) или как южноэстонская и североэстонская (Каяк, 1963) стадии. Краевые образования более древней, крестецкой стадии (или фазы) отстоят от рассматриваемой нами территории сравнительно далеко (они развиты вдоль карбонового уступа и по краям Бежаницкой и Судомской возвышенностей), но местами в ЧудскоПсковской впадкне, видимо, встречается морена и этой стадии.

После крестецкой стадии, как известно, наступил плюсский (Вигдорчик и др., 1962), или раунисский (бурзавский) (Савваитов, Страуме, 1963; Савваитов и др., 1964 и др.), межстадиал (межфазиал), во время которого на западе Ленинградской области и на востоке Латвии произрастали сосново-березовые леса с примесью ели и ольхи. По присутствию остатков перигляциальных растений (таких, как Betula nana, Salix polaris, Dryas octopetala и др.) можно сделать вывод о довольно суровых климатических условиях этого межстадиала (Серебрянный, Раукас, 1966, 1967). Время существования плюсского (раунисского) межстадиала - 13500 - 13200 лет назад, а продолжительность его не более 500 лет (Серебрянный, Раукас, 1966). Ледники в результате плюсского (раунисского) потепления освободнли, вероятно, Псковскую низину и южную часть впадины Чудского озера. По Э. Саммету (1965), льды во время плюсского межстадиала освободили даже предглинтовую низменность, где в это время, как он полагает, распространялся обширный и глубокий озерный бассейн, в котором накопились осадки мощностью до 25 м, а Чудское озеро было несколько шире современного. Учитывая продолжительность упомянутого межстадиала и средние скорости отступания ледникового покрова, справедливость этого представления может быть поставлена под сомнение.

Во время наступания ледника лужской (хааньяской) стадии отложения плюсского времени были бо́льшей частью уничтожены. В пределах впадины Чудского и Псковского озер ледники этой стадии наступали в основном с севера на юг, но под влиянием подстилающего рельефа местами изменяли направление своего движения (Raukas, 1961 и др.). Краевые образования лужской стадии, существовавшей примерно в интервале от 13200 до 12700 лет назад (Пуннинг и др., 1968), окаймляют в виде боковых и конечных морен современное Псковское озеро и далее продолжаются на склонах Хааньяской возвышенности, которая в указанное время представляла собой межъязыковый массив.

В ходе отступания ледников лужской стадии из впадины Чудского и Псковского озер неоднократно происходили временные надвигания и более или менее продолжительные остановки ледникового края. Во время отепяской фазы ледники интенсивно продвигались вперед по депрессии между Сакаласким и Угандиским плато и по Чудско-Псковской впадине, образуя классически выраженные краевые формы льда в районе Карула и по линии Кулье - п-ов Лисье - п-ов Будовищи - о-в Каменка - Талабские о-ва - Елизарово (Раукас, Ряхни, 1966). Отепяская возвышенность оставалась между двумя отмеченными выше ледниковыми дугами в виде межъязыкового массива. На ней были широко распространены мертвые льды с многочисленными небольшими 
локальными озерно-ледниковыми бассейнами, имевшими весьма различные абсолютные высоты, наиболее часто от 120 до $170 \mathrm{M}$.

Кроме довольно продолжительной остановки края ледника на линии Кулье - Талабские о-ва - Елизарово, в пределах впадины Чудского н Псковского озер отмечались более длительные остановки края льда еще в окрестностях Мехикоорма и Пнево (где край ледника маркируется холмисто-моренным рельефом с формами напора и небольшими флювиогляциальными дельтами), примерно по линии Лаэва - Ывикюла Кобрату-о-в Пийриссаар-Княжья Гора (где положение края ледника маркируется главным образом маргинальными камами, зандрамп и крупными ложбинами стока талых ледниковых вод), по линии Сиймусти-Калеви-Визузи-Эхавере-Вайдавере-Сельгузе (где наблюдаются маргинальные камы и разные флювиогляциальные образования), в районе Кайу и г. Гдова (где край ледника маркируется маргинальными камами и конечными моренами), близ камового поля Тёльязе и по линии Авинурме-Тудулинна-Катазе. Во время последней остановки, тудулиннаской осцилляции по К. Каяку (Kajak, 1964), формировалась флювиогляциальная дельта близ населенного пункта Тудулинна. Отдельные отмеченные выше остановки края льда местами сопровождались новыми надвигами льдов, в частности в район Кайу и г. Гдова, где соответственно образовались краевые формы предельного распространения ледников пандивереской (невской) стадии или фазы (Эльтерманн, Раукас, 1963; Раукас, Ряхни, 1966). Это кратковременное наступание, вероятно, происходило в интервале от 12200 до 11900 лет назад, т. е. в среднем дриасе (Серебрянный, Раукас, 1966, 1967).

В связи с постепенным убыванием ледяного покрова лужской (хааньяской) стадии во впадине Псковского озера и в южной части впадины Чудского озера сформировалось крупное подпрудное озеро Древний Пихква по К. Орвику (Orviku, 1959), которое имело следующие более постоянные уровни: около $95 ; 85 ; 75 ; 70 ; 60 ; 50$ и 38 м. Уровни с абсолютными высотами 70 м и выше мы относим к Первому Псковскому приледниковому озеру (PiI), а уровни ниже 70 Второму Псковскому приледниковому озеру (PiII). Д. Квасов и И. Краснов (1965) предполагают, что Псковское приледниковое озеро являлось частью крупного Привалдайского ледникового озера, которое в начальный период своего развития могло иметь сток в бассейн Волги или в Белое море, а затем через долину Выру-Харгла в р. Гаую.

Ввиду того что данные о суммарном поднятии земной коры в пределах Псковской впадины являются спорными и недостаточно обоснованы геологическими данными, то схемы распространения Псковского приледникового озера (рнс. $1-5$ ) составлены без учета поднятия земной коры.

Уровень несколько выше 95 м (фаза РіІа) определяется по ровным гребням камов и разных флювиогляциальных образований в Мустояском камовом поле и вблизи него. Он образовался в Псковской низине во время максимума отепяской фазы, когда край ледника стоял на линии Кулье-Талабские острова-Елизарово (рис. 1). Талые воды ледника текли из приледникового озера через расположенную между возвышенностями Хаанья и Отепя ложбину в р. Гаую. На Отепяской (частично и на Хааньяской) возвышенности располагались мертвые льды.

После фазы PiІа уровень воды в бассейне сравнительно быстро (возможно с кратковременной остановкой на высоте около $84-85$ м) упал до абс. отметок 75-76 м. В связи с этим сток воды к западу постепенно уменьшался, а затем почти прекратился, о чем свидетельствует высота древней долины близ Табина (около 75 м), соединяющей Пиузаскую 


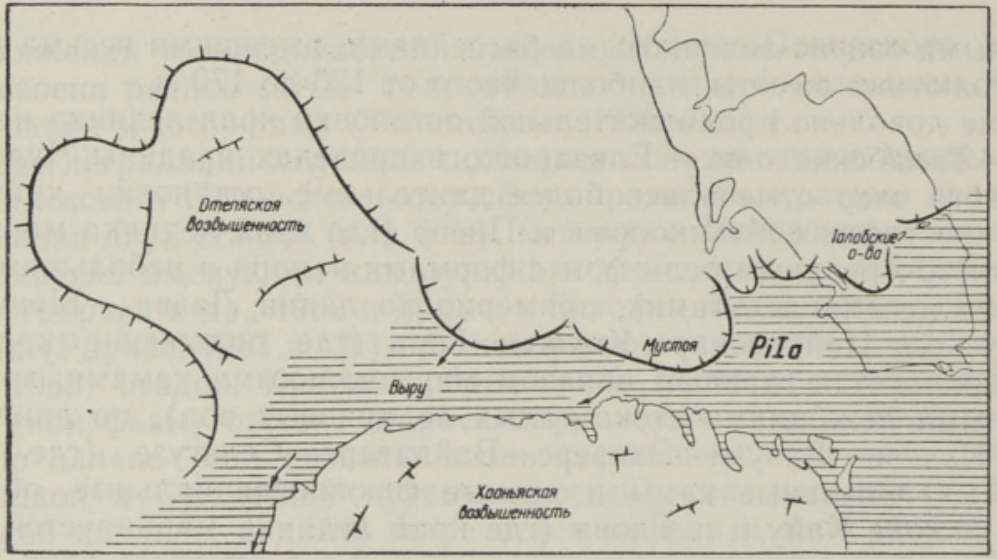

Рис. 1. Расположение края материкового льда и Псковского приледникового озера во время фазы PiІа.

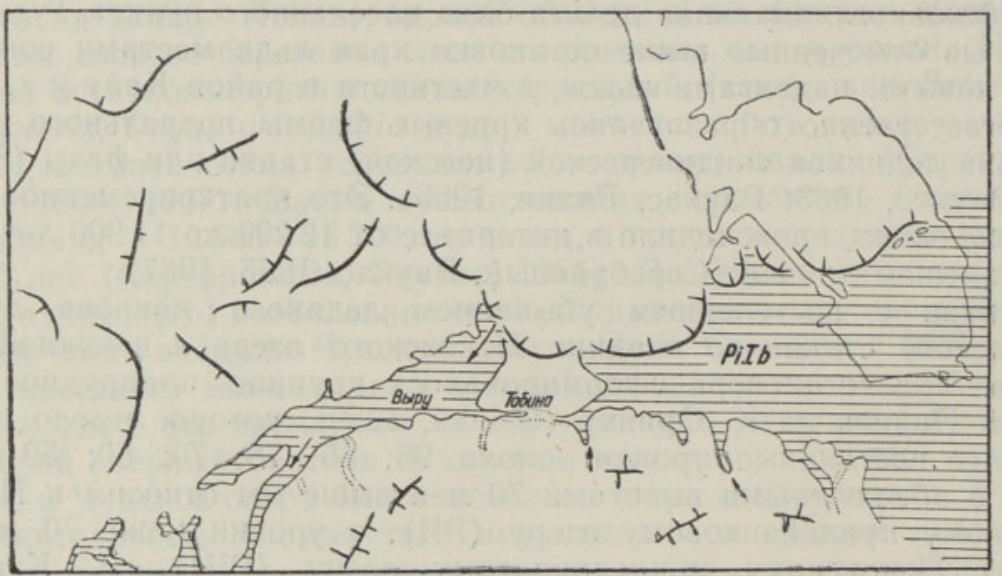

Рис. 2. Расположение края матернкового льда и Псковского приледниковогс озера во время фазы Pilb.

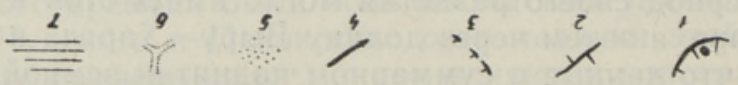

Условные обозначения к рис 1-8: $t-$ край ледника: 2 - крупные трещины в леднике н поля мертвого льда; 3 - возможное расположение края льда (без нзличня четко выраженных краевых форм рельефа): 4 - направления движения талых вод ледника: 5 - свободная ото льда территорня; 6 - долины: 7 - занлтые озером территории.

древнюю долину и Вырускую впадину. Воды в это время (фаза PiIb) не могли течь к западу также по Выхандуской долине, абсолютная высота днища которой составляет тоже около 75 м. Видимо, в конце фазы Pilb по долине Выру-Харгла текли лишь талые воды, поступившие с Отепяской возвышенности и из окружающих ее районов, в частности из района Лээви (рис. 2). Во время фазы PiIb и до ее начала образовались террасы в долине р. Пиузы и в западной части древней долины Выру-Печоры на абсолютных отметках до 95 , около 88 , около 84 (82-85) и 76 (75-78) м (Liblik, 1966; Hang, Liblik, Linkrus, 1964).

Сток из приледникового озера в направлении Выру-Харгла на короткое время возобновился в следующую фазу - PiІc, когда край лед- 


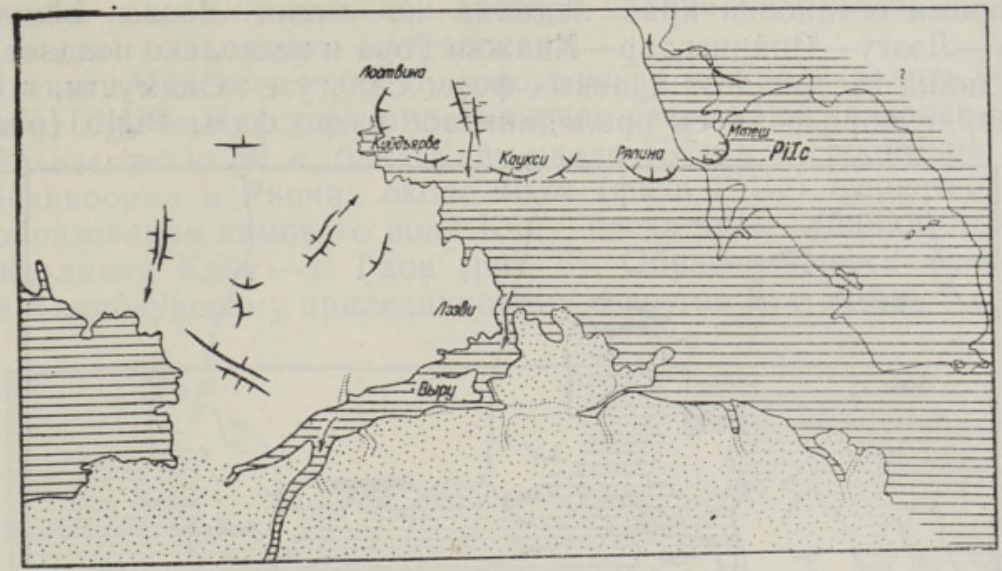

Рис. 3. Расположение края материкового льда и Псковского приледникового озера во время фазы PiIc.

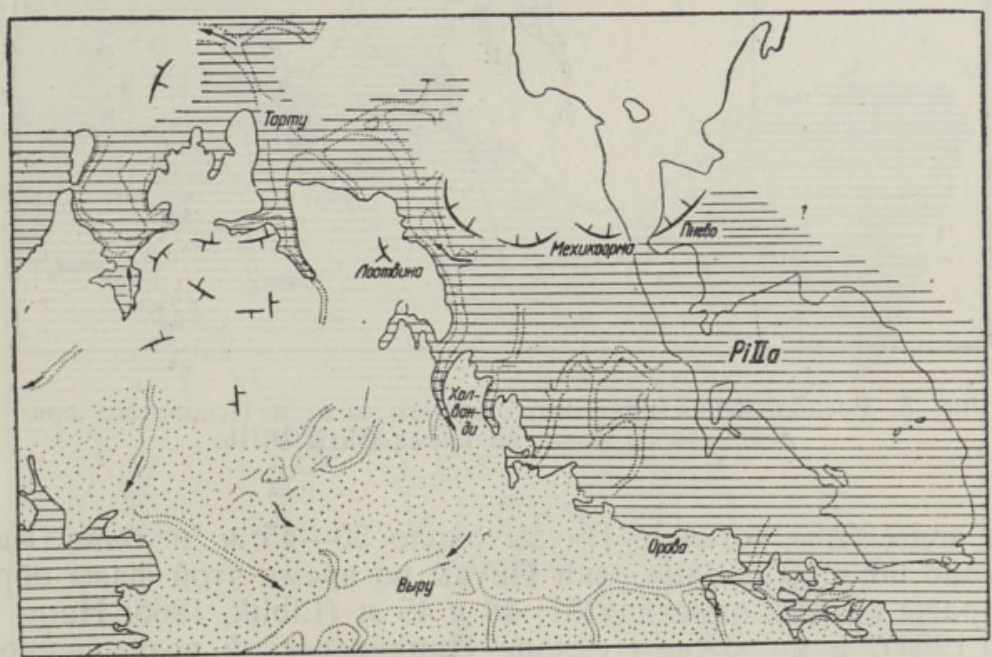

Рис. 4. Расположение края материкового льда и Псковского приледннкового озера го время фазы PiIIa.

ника стоял примерно на линии Лоотвина-Кийдъярве-Каукси-Ряпина-Мтеш и ото льда освободилась сквозная долина близ Лээви (рис. 3 ). Судя по высоте флювиогляциальных образований близ Лоотвина и Қийдъярве, уровень воды в озере в эту фазу составлял около 70 м. Возможно, что этому уровню соответствуют террасы в долине р. Пиузы на абс. отметках около $72(71-73)$ м (Liblik, 1966).

Когда уровень воды в озере понизился до отметок $62-60$, то в Псковской низине образовалась первая фаза Второго Псковского приледникового озера PiIIa, уровень которой отражают уступы близ Орава и Холванди (рис. 4) и террасы группы B (Liblik, 1966; Hang, Liblik, Linkrus, 1964) в долине р. Пиузы на абс. отметках около 62 и 60 м. Край ледника в эту фазу стоял на линии Мехикоорма-Пнево. Сток воды из озера был ограничен и происходил, видимо, лишь в северозападном направлении, по долинам Ахья и Суур-Эмайыги, в окрестностях которых широко распространялись мертвые льды. 
Во время остановки края ледника на линии Лаэва-ЫвикюлаКавасту-Лээгу-Пийриссаар-Княжья Гора и несколько позднее, когда край ледника отступил от краевых форм Сельгузе-Сиймусти, в Псковской низине образовалось приледниковое озеро фазы PiIlb (рис. 5) с

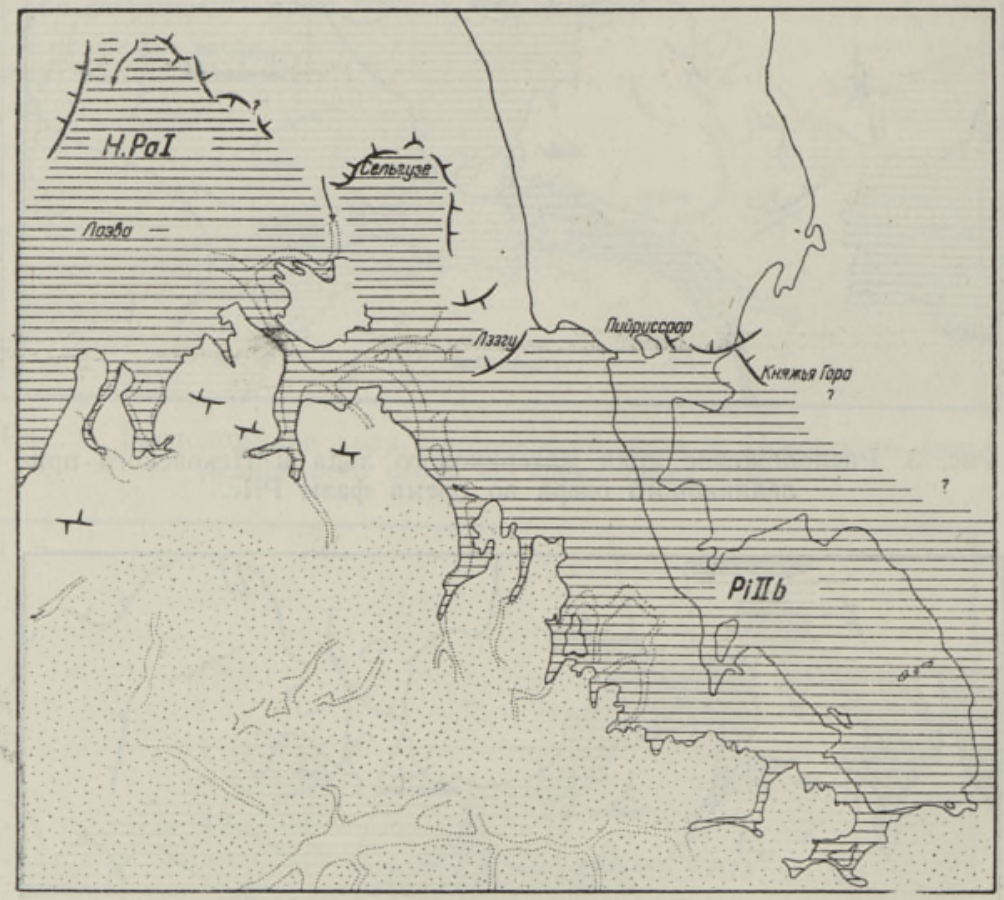

Рис. 5. Расположение края материкового льда и Псковского приледникового озера во время фазы PiIIb.

уровнем воды близ устья р. Пиузы около $50-45$ м и близ Княжьей Горы около 60 м. В долине реки Пиузы во время этой фазы образовались террасы на абс. отметках 51; 48 и 45 м (Liblik, 1966; Hang, Liblik, Linkrus, 1964), а на южном склоне Пандивереской возвышенности Пандивереское ледниковое озеро $\mathrm{HPaI}$, синхронное озеру PiIIb (Ряхни, 1967), уровень которого, судя по высоте ровных гребней камов в камовом поле Сельгузе, находился на высоте около 85-90 м над у. м. Сток из обоих связанных между собой озер происходил на запад, в сторону низины озера Выртсъярв. Приведенное не согласуется с данными X. Хаузена (Hausen, 1913), по мнению которого во время остановки ледникового края близ о-ва Пийриссаар в южной части современного Чудского озера и в пределах современного Псковского озера располагалось крупное подпрудное Псковское приледниковое озеро с уровнем воды не ниже $75 \mu$, сток из которого происходил через Выру и ВалгскоВалмиерский зандр в р. Гаую и далее в Рижский залив.

Наступающие ледники пандивереской (невской) стадии несколько подпруживали приледниковые воды, и перед краем льда образовалось Чудское приледниковое озеро, отмеченное в литературе уже В. Рамзаем (Ramsay, 1929). Сток из Чудского приледникового озера (Древний Пейпси по К. Орвику, 1959) происходил в основном вдоль долины СуурЭмайыги на запад, а затем через крупное приледниковое озеро Древний Выртсъярв (Л. Орвику, 1958) по долине Вяйке-Эмайыги в южном 
направлении и по Вильяндиской древней долине (возможно, и по ложбине Навести) в западном направлении.

В развитии Чудского приледникового озера можно выделить несколько этапов. Первое Чудское приледниковое озеро (PeI) с уровнем воды близ Тёльязе около 86 , близ Кайу около 75 м и в Псковской низине близ Мехикоорма и Ряпина около 40 м (фаза PiIIc) существовало во время образования камового поля Кайу, когда край ледника стоял примерно на линии Кайу - г. Гдов (рис. 6). Образовавшееся озеро, синхронное Южночудскому приледниковому озеру по Х. Хаузену * (Hausen,

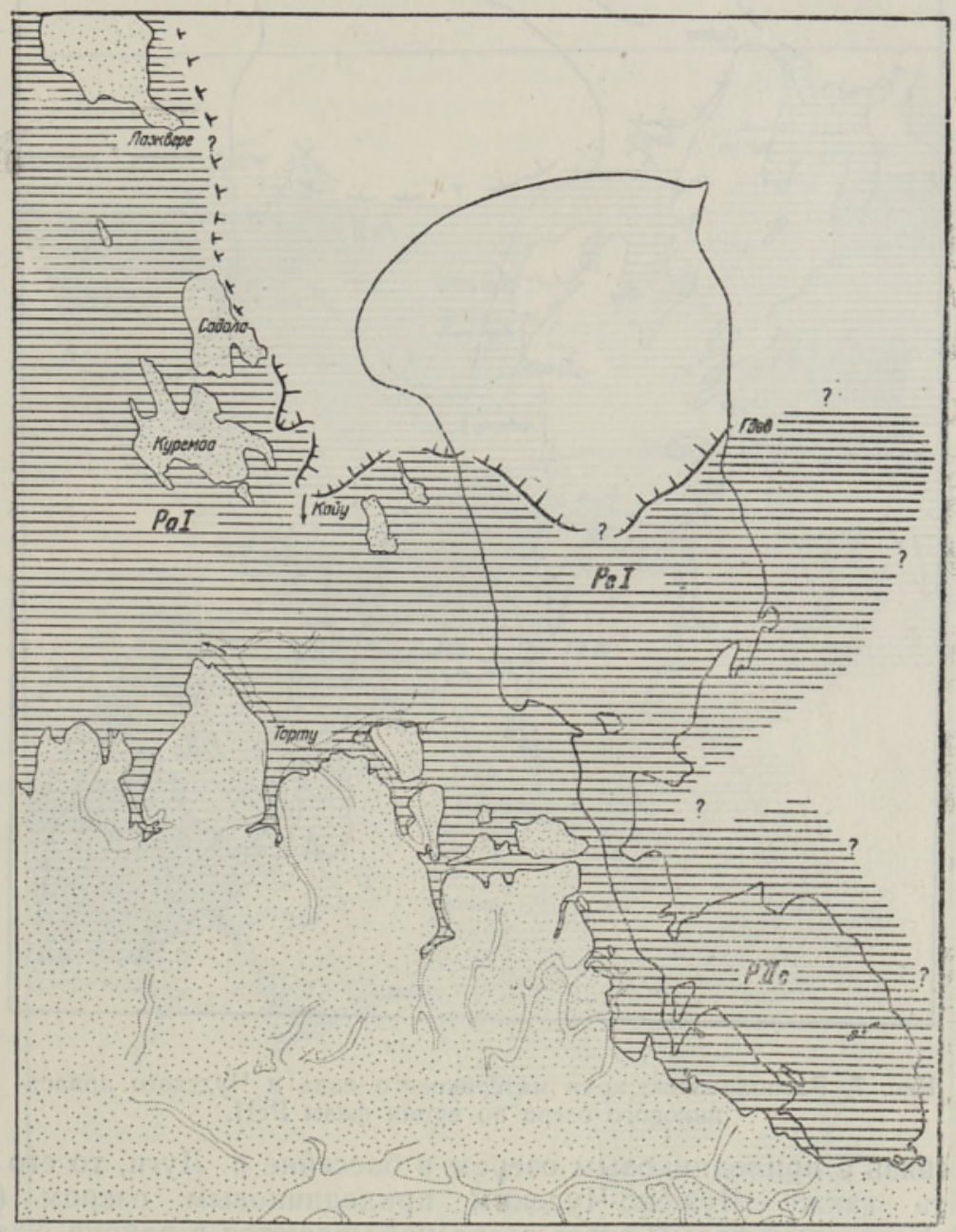

Рис. 6. Расположение края материкового льда и Чудского приледникового озера во время фазы PeI.

1913), имело сложные контуры. Из-под воды выступали многочислен-ные острова, в частности в пределах Саадъярвского друмлинового поля (о-ва Куремаа, Садала и др.).

* Уровень воды I Чудского прнледникового озера не совпадает с уровнем Южночудского приледникового озера X. Хаузена. 
Воды Второго Чудского приледникового озера (PeII), несмотря на то, что его уровень был примерно на 15 м ниже первого, затопили обширные территории (рис. 7). Так как II Чудское приледниковое озеро

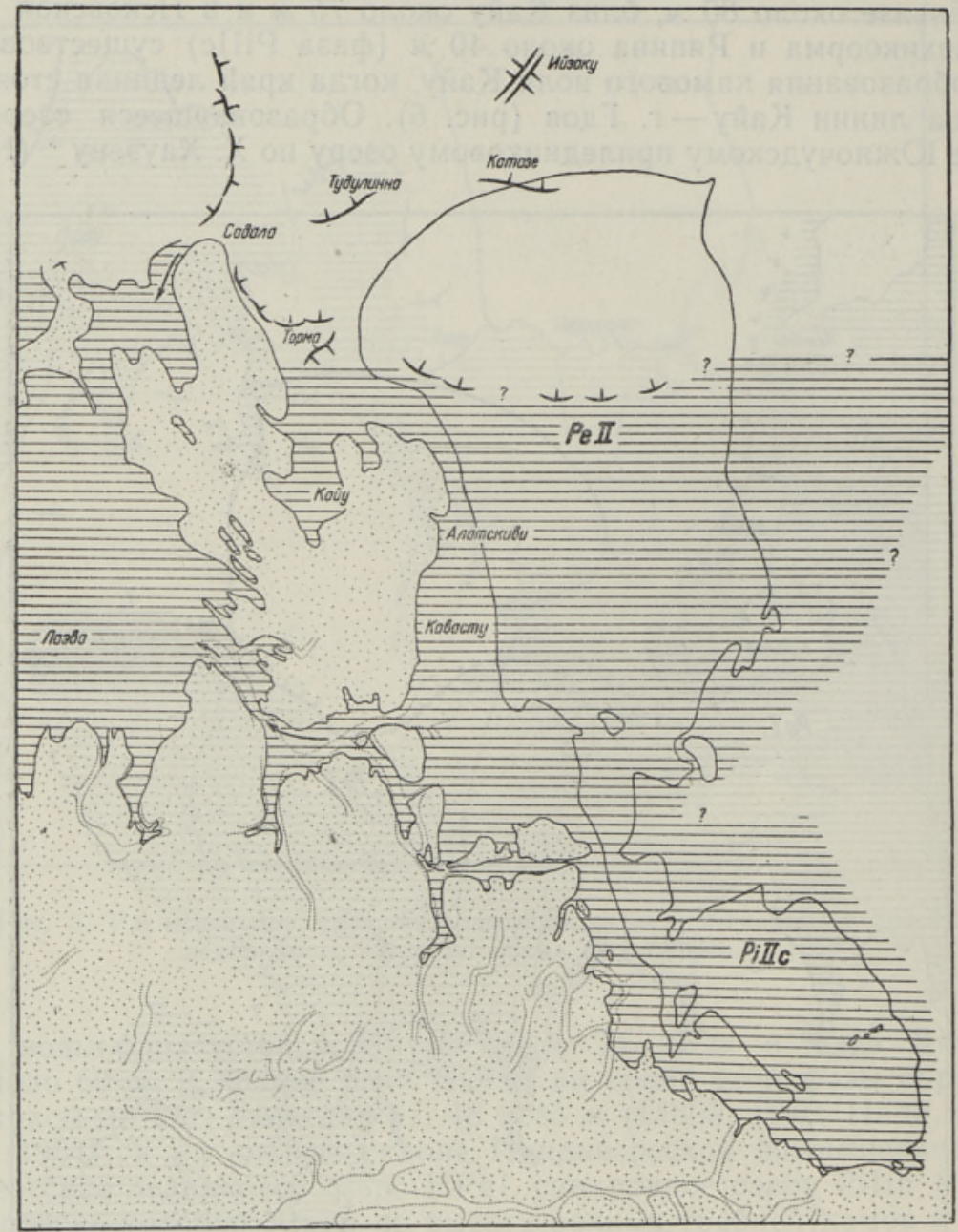

Рис. 7. Расположенне края материкового льда и Чудского приледникового озера во время фазы PeII.

имело связь с приледниковым озером в бассейне р. Луги, то его можно называть также Лужско-Чудским приледниковым озером (Ряхни, 1963а). Береговые формы этого озера наблюдаются в районе Алатскиви на высоте около 55 м. Край ледника во время распространения II Чудского приледникового озера находился примерно на линии ТудулиннаКатазе. Сток из озера происходил по древней долине р. Суур-Эмайыги и через Поомиский пролив в пределах затопленного водами Саадъярвского друмлинового поля близ Садала. Во время фазы РеII благодаря прорыву озера близ с. Копорье (Марков, 1931) произошло слияние Лужско-Чудского и Невского плотинных озер. Э. Саммет (1965) предлагает считать это событие началом существования на рассматриваемой территории I Балтийского ледникового озера. Предложение это, однако, является дискуссионным. 
Третье Чудское приледниковое озеро (PeIII) соединялось через долину р. Суур-Эмайыги с крупным приледниковым озером $A_{1}$ (по К. Пярна, 1962 и др.), которое распространялось на западном и восточном склонах Пандивереской возвышенности, в низине Выртсъярв, на северо-западном склоне возвышенности Сакала, а также в более низменных частях Южной и Западной Эстонии (рис. 8). Озеро PeIII соответствует приблизительно Большому Пейпси по Х. Хаузену (Hausen, 1913). Высота уровня III Чудского приледникового озера была близ Саара около 80 м, близ Ийзаку около 70 м, близ Кодавере около 50 м,

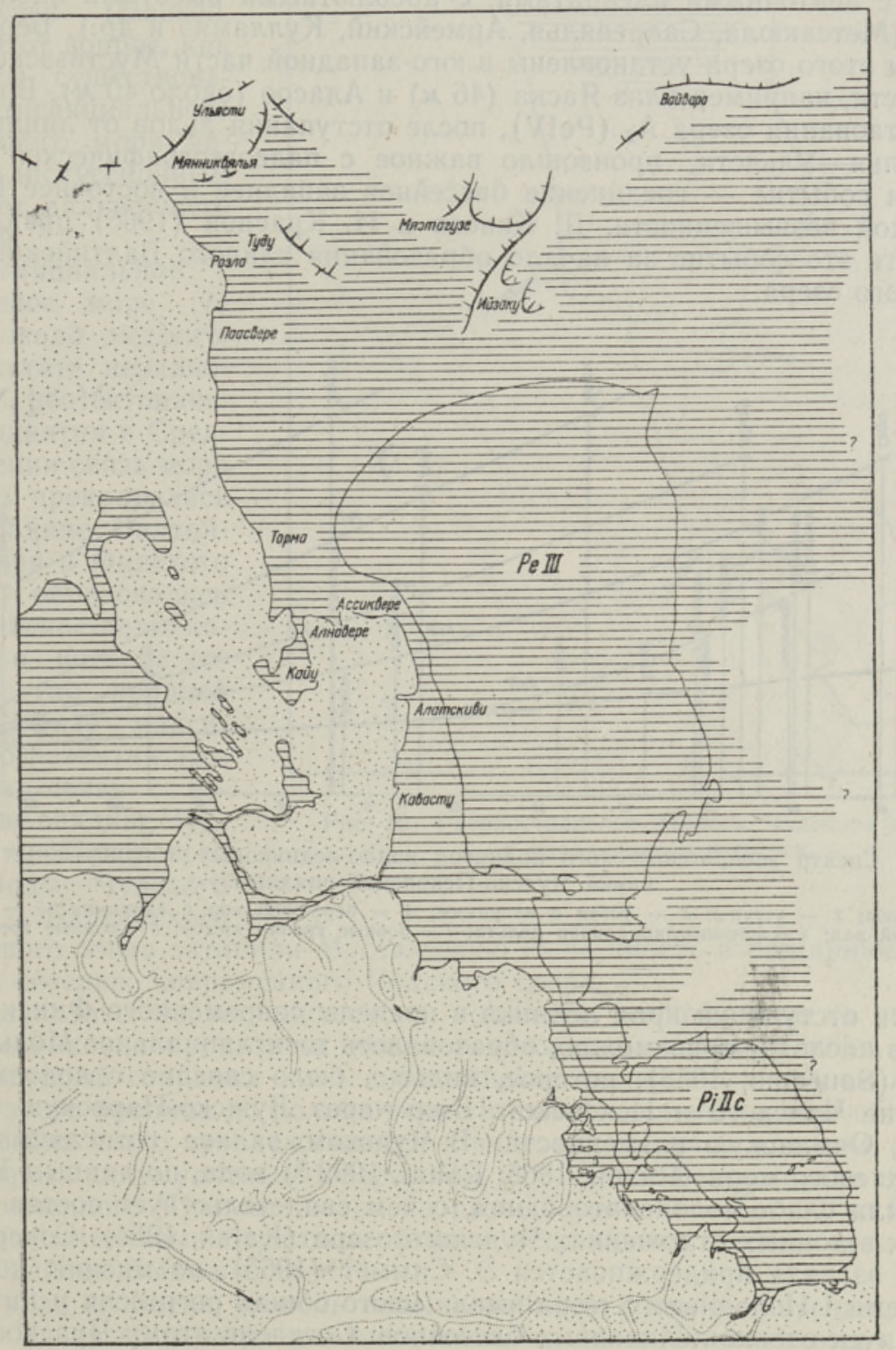

Рис. 8. Расположение края материкового льда и Чудского приледникового озера во время фазы Pelli. 
близ Кавасту около 43 м, а в Псковской низине около 38 м. Край ледника находился, видимо, на линии Ийзаку-Мяэтагузе-ВайвараЛаагна и на восточном склоне Пандивереской возвышенности близ Мянниквялья и Ульясти. Местами встречались мертвые льды.

Четвертое Чудское приледниковое озеро (PeIV) сопоставляется нами с уровнем $\mathrm{A}_{2}$ (по К. Пярна, 1962 и др.), когда край активного ледника стоял между Палукюла, Пюхамяэ и Кемба, а в Северо-Восточной Эстонии на обширной территории происходило образование форм мертвого льда. В это время наряду с другими формами в окрестностях Ийзаку и Мяэтагузе (Ряхни,' 1963б) образовались лимногляциальные камы с ленточными алевритами, с абсолютными высотами около 6252 м (Метсакюла, Сааревялья, Армейский, Кулламяэ и др.). Береговые формы этого озера установлены в юго-западной части Муствээской низменности, например близ Яаска $(46$ м) и Аласоо (около 40 м). Во время существования озера $\mathrm{A}_{2}$ (PeIV), после отступания льдов от линии Мянниквялья-Ульясти, произошло важное с палеогеографической точки зрения событие - соединение бассейнов западнее и восточнее Пандивереской возвышенности. Д. Квасов и И. Краснов (1965) предлагают принять это событие за начало образования единого Балтийского ледникового озера.

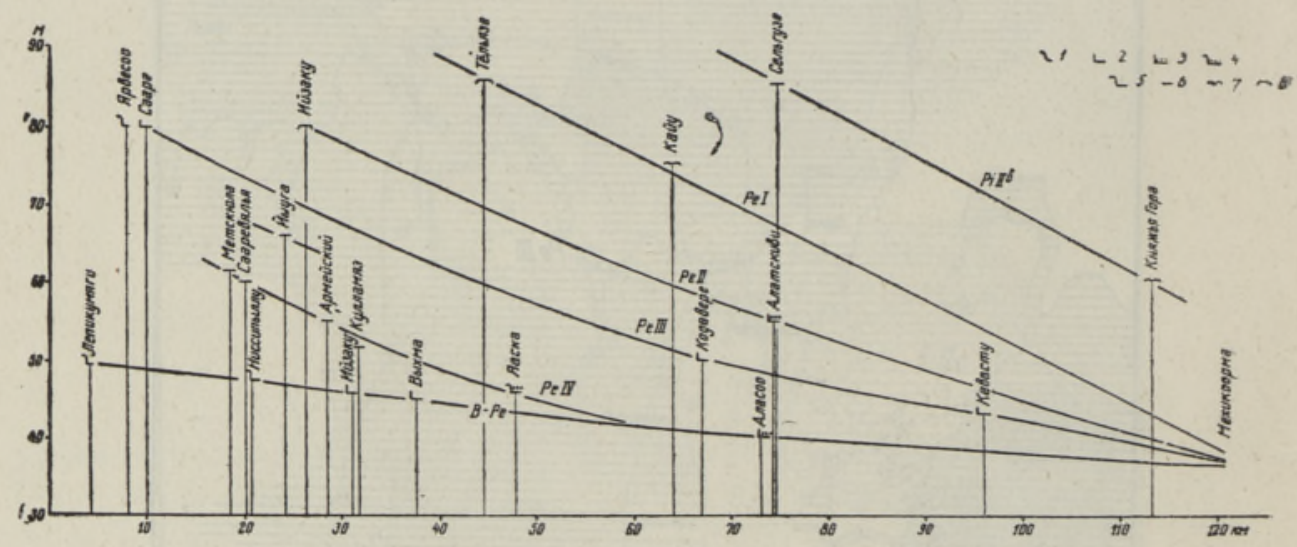

Рис. 9. Спектр эпейрогенического поднятия водно-ледниковых и прибрежных образований Чудско-Псковской впадины.

1 - дюны; 2 - уступы; 3 - уступ с валунами; 4 - береговой вал с валунами; 5 - уступ и береговой вал; 6 - флювиогляциальная дельта; 7 - ровные гребни камов; 8 - ровные гребни озов.

При отступании края ледника в пределы современного Финского залива в последнем, возможно, образовалось готигляциальное Иольдиевое море (Sauramo, 1958), которое, видимо, было связано с водоемом во впадине Чудского и Псковского озер через Лужско-Нарвскую и, частично, Оямааскую низменности. В Чудском заливе готигляциального Иольдиевого моря (Ряхни, 1965; Rähni, 1962 *) вода, по данным К. Каяка, была слабо солоноватоводная, о чем свидетельствует состав диатомовых в донных отложениях Чудского озера (Kajak, 1964). Совершенно иного взгляда придерживается Э. Саммет (1965), по мнению которого во время I Иольдиевого моря имели место общая регрессия и интенсивный спуск озерно-ледниковых бассейнов. Согласно этому Чудское озеро

* E. Rähni, 1962. Jääjärveliste setete iseloomust Peipsi järve madaliku :ōunaosas. Рукопись в фондах ИГ АН ЭССР. 
отделилось от остальных бассейнов и имело несколько меньшую площадь, чем современное озеро. Об интенсивной регрессии бассейнов после отступания края ледника от краевых форм Ийзаку-. Иллука говорит также Х. Хаузен (Hausen, 1913). Этот вопрос, как и вопрос существования готигляциального Иольдиевого моря, является дискуссионным и требует дальнеӥшего изучения.

Готигляциальное

Иольдиевое море (?) существовало недолго. В результате неравномерного неотектонического поднятия в Средней Швеции связь моря с океаном прекратилась и во впадине Балтийского моря и Финского залива образовалось II Балтийское ледниковое озеро, которое сохраняло (по крайней мере в фазу максимального развития этого озера) связь с водоемом во впадине Чудского и Псковского

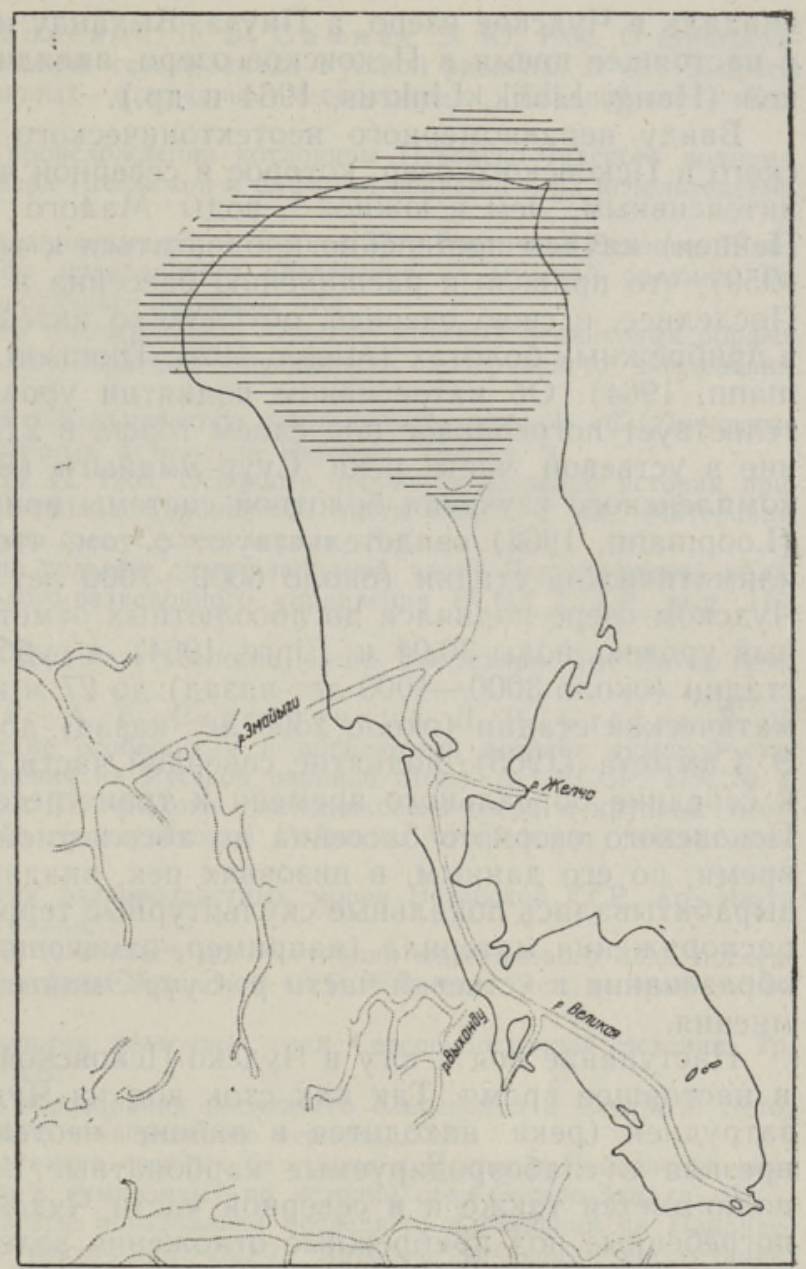

Рис. 10. Распространение Малого Чудского озера и впадающих в него рек. озер. Воды Чудского залива Балтийского ледникового озера затопили Муствээскую низменность и обширные территории севернее современного Чудского озера.

В результате неотектонического поднятия земной коры в конце позднеледниковья произошла общая регрессия бассейна (Orviku, 1959 и др.), который сохранил связь с Балтийским ледниковым озером лишь в виде узкого пролива по долине реки Нарвы. Отдельные этапы обмеления бассейна четко прослеживаются в виде абразионных уступов, склонов и разных аккумулятивных береговых форм рельефа несколько севернее современного Чудского озера на разных уровнях - от 50 до $37 \mathrm{M}$. Наиболее отчетливые береговые формы встречаются на высоте около 40 м (в районе Выхма и др.).

В начале голоцена уровень воды понизился столь значительно, что впадина Псковского озера и южная часть впадины Чудского озера осушились и озеро сохранилось лишь в северной части впадины Чудского озєра (рис. 10). Образовалось так называемое Малое Чудское озеро (Старое Пейпси по К: Орвику; Orviku, 1959). Река Великая в это время 
впадала в Чудское озеро, а Пиуза, Выханду и другие реки, впадающие в настоящее время в Псковское озеро, являлись притоками реки Великой (Hang, Liblik, Linkrus, 1964 и др.).

Ввиду неравномерного неотектонического поднятия впадины Чудского и Псковского озер, которое в северной части впадины было более интенсивным, чем в южной *, воды Малого Чудского озера (Малого Пейпси) начали постепенно продвигаться к югу (Hausen, 1913; Orviku, 1959), что привело к расширению бассейна и поднятию грунтовых вод. Последнее, в свою очередь, обусловило интенсивное торфообразование в прибрежных болотах (Mieler, 1926; Thomson, 1939; Orviku, 1959; Loopmann, 1964). Об интенсивном поднятии уровня воды наглядно свидетельствует погребенное под слоем торфа в 2,5 м неолитическое поселение в устьевой части реки Суур-Эмайыги (Янитс, 1959). Результаты комплексного изучения болотной системы приустья реки Суур-Эмайыги (Loopmann, 1964) свидетельствуют о том, что к началу атлантической климатической стадии (около 6000-7000 лет назад) уровень воды в Чудском озере поднялся до абсолютных отметок около 25 м (современный уровень воды 30,04 м; Eipre, 1964), в суббореальной климатической стадии (около 3000-4000 лет назад) до 27 м и в субатлантической климатической стадии (около 2500 лет назад) до 28,5-29,0 м. По мнению Э. Саммета (1965), поднятие северной части озерной впадины привело к середине бореального времени к трансгрессии южной части ЧудскоПсковского озерного бассейна до абсолютной высоты 35-36 м. В это время, по его данным, в низовьях рек, впадающих в Псковское озеро, вырабатывались локальные скульптурные террасы. Имеющийся в нашем распоряжении материал (например, отмеченные выше данные о торфообразовании в устьевой части р. Суур-Эмайыги) не подтверждает этого мнения.

Наступание вод к югу в Чудско-Псковской впадине продолжается и в настоящее время. Так как сток вод из Чудского озера по р. Нарве затруднен (река находится в районе неотектонического поднятия и врезана в слабоэродируемые карбонатные породы), то уровень воды поднимается также и в северной части Чудского озера, о чем говорят погребенные под прибрежные отложения залежи торфа, затопленные в недалеком прошлом острова, интенсивная абразия берега и т. д. Особенно мощные слои органики (до 1 м) обнаружены под озерными (возможно, под аллювиальными) отложениями близ Омеду и в долинах Ранна-Пунгерья, Алайыэ, Тудулинна и Роостоя. Возраст пня дуба из-под озерных (?) песков в долине Алайыэ определен в лаборатории геобиохимии Института зоологии и ботаники АН ЭССР Я.-М. Пуннингом в $910 \pm 200$ лет (ТА-159), что согласуется с условиями залегания органогенного материала.

В заключение необходимо отметить, что наши выводы основываются главным образом на материалах изучения западной части ЧудскоПсковской впадины и поэтому не являются исчерпывающими.

\section{ЛИТЕРАТУ РА}

Алейников А. А. 1957. Отступание ледника в северо-западной части Русской равнины (стадки н осцилляцин). Научн. сообщ. Ин-та гесл. и геогр. АН Лнт. CCP, IV. Вильнюс.

А лейни ко в А. А. 1960. Об основных вопросах изучения четвертичных (антропогеновых) отложений Северо-Запада СССР. Изд. ЛГУ.

* По Э. Саммету (1965), за последние 12000 лет амплитуда неотектонического поднятия на побережье Финского залива составляла около 60 м, в районе г. Кингисеппа - около 35 и и в районе г. Пскова - не более $15-20 \mathrm{M}$. 
Вигдорчик M. Е., М алаховский Д. Б., С аммет Э. Ю. 1962. О стратиграфии четвертичных отложений северо-запада Русской равнины. В сб.: Вопросы стратиграфии четвертичных отложений северо-запада Европейской части СССР. Л.

И са ченков В. А. 1966. О происхождении котловины Псковско-Чудского водосма. Тезисы докл.: Малые озера Псковской и смежных областей и их использованне. Псков.

К а я к К. Ф. 1963. О краевых ледниковых образсваниях Юго-Восточной Эстонии. В сб.: Краевые формы рельефа материкового оледенения на Русской равнине. Тр. Ком. по изучению чствертичного периода. XXI.

К а я К К. Ф. 1965а. Особенности геологического строения краевых ледниковых образований в Эстонии. В сб.: Краевые образования материкового оледенения. Вильнюс.

К а я К К. Ф. 1965б. К геологии Саадъярвского друмлинового поля. В сб.: Литология и стратиграфия четвертичных отложений Эстонии. Таллин.

К васов Д. Д., К р а сно в И. И. 1965. Основные проблемы изучения истории приледниковых озер северо-запада Европейской части СССР. В кн.: Материалы к симпозиуму по истории озер Северо-Запада. Л.

М а рков К. К. 1931. Развитие рельефа северо-западной части Ленинградской области. Тр. Главного геолого-разведоңного управления ВСНХ СССР, вып. 117. М.-Л.

Ор вику Л. Ф. 1958. Новые данные о геологии озера Выртсъярв. Тр. Ин-та геол. АН ЭССР, III. Таллин.

Пуннинг Я.-М. К., Р аукас А. В., Серебрянный Л. Р., Стелле В. Я. 1968. Палеогеографические особенносги и абсолютный возраст лужской стадии валдайского оледенения на Русской равнине. Докл. АН СССР, 178. № 4.

Пя н а К. Т. 1962. О геэлогии Балтийского приледникового озера и крупных местных приледннковых озер на территории Эстонии. Автореферат диссертации. Таллин.

Р а ука с А. В. 1963. Литология разновозрастных морен Эстонской ССР. Тр. Ин-та геол. АН ЭССР, ХІІ. Таллин.

Р а ука с А., Р я н и Э. 1966. К вопросу об отступании материкового льда последнего оледенения ₹ территории Эстонской ССР. Ежегсдн. Эст. географ. об-ва 1964/1965. Таллин.

Р яхни Э. Э. 1963а. Геохронология ленточных глин Северо-Восточной Эстонии. Тр. Ин-та геол. АН ЭССР, ХII.

Р яхни Э. Э. 1963б. Краевые образования последнего оледенения в Северной Эстонии. Тр. Ком. по изучению четвертичного периода, XXI.

Р я хни $Э . Э .1965$. История развития озерных бассейнов в Псковско-Пейпсиской впадине. В кн.: Материалы к симпозиуму по истории озер Северо-Запада. Л.

Р я н и Э. Э. 1967. Озы и краевые образования последнего оледенения на Пандивереской возвышенности (Эстонская ССР). Автореферат канд. диссертации. Таллин.

С а в в а и то в А. С., С т р у м е Я. А. 1963. К вопросу о стратиграфической двучленности покрова морены валдайскогс оледенения в междуречье нижних течений рек Даугава и Гауя. В кн.: Вопрссы четвертичной геологии, II (Тр. Ин-та геол. АН Латв. ССР, ІІ). Рига.

С а в в а и тов А. С., С телле В.Я., К р ул е М. Я. 1964. О стратиграфическом расчленении отложений валдайского оледенения на территории Латвийской ССР. В кн.: Вопросы четвертичной геслогии, III. Рига.

С а м м т Э. IO. 1965. Основные этапы развития некоторых типов приледниковых озер в западной части Ленинградской и Псковской областей. В кн.: Материалы к симпозиуму по истории озер Северо-Запада. Л.

Сереб́рянны й Л. Р., Р а ук а с А. В. 1966. Трансбалтийские корреляции краевых ледниковых образований позднего плейстоцена, В кн.: Верхний плейстоцен. Стратиграфия и абосолютная геохронслсгия. М.

С ере брянн ый Л. Р., Р а ук а с А. В. 1967. Сопоставление готигляциальных краевых ледниковых образований во впадине Балтийского моря и прилегающих к ней странах. В кн.: Baltica, 3. Вильнюс.

Эльтерм анн Г. Ю., Р аукас А. В. 1963. Некоторые примеры сопоставления макроскопически сходных разновозрастных морен на основе их литологическогс изучения. Тр. Ин-та геол. АН ЭССР, ХІІ. Таллин.

Я н и с Л. Ю. 1959. Поселение эпохи неолита и рапнего металла в приустье р. Эмайыги (Эстонская ССР). АН ЭССР. Таллин.

Grew ing k C. 1879. Erläuterungen zur zweiten Ausgabe der geognostischen Karte Liv-, Est- u. Kurlands. Arch. Naturk. Liv-, Ehst- u. Kurl., Ser. 1. Bd. 8. Dorpat.

E i p re T. 1964. Peipsi-Pihkva järve veeseisud. Eesti Geograafia Seltsi Aastaraamat 1963. Tallinn. 
$\mathrm{H}$ a ng E., Liblik T, Linkrus E. 1964. On the relations between Estonian valley terraces and lake and sea levels in the late-glacial and holocene periods. Transactions of the Tartu State. University, 156. Publications on geography, IV.

Ha usen H. 1913. Ober die Entwicklung der Oberflächenformen in den russischen Ostseeländern und angrenzenden Gouvernements in der Quartärzeit. Fennia, 34, 3. Helsingfors.

K a j a k K. 1964. Peipsi nōo geoloogiast ja geomorfoloogiast. Eesti Geograafia Seltsi Aastaraamat 1963. Tallinn.

L i b lik T. 1966. Jooni Piusa oru geomorfoloogiast. Eesti Geograafia Seltsi Aastaraamat 1954/65. Tallinn.

L o opmann A. 1964. Ulevaade Emajōe suudmeala soostikust. Eesti Geograafia Seltsi Aastaraamat 1963. Tallinn.

Mieler A. 1926. Ein Beitrag zur Frage des Vorrückens des Peipus an der Embachmündung und auf der Peipusinsel Piirisaar in dem Zeitraum von 1682 bis 1900. Acta Univ. Tartu, A. IX, 2.

O rviku K. 1959. Peipsi järve minevikust. Rahva Hääl, 214, 11. sept. 1959.

$\mathrm{R}$ a m s a y W. 1929. Niveauverschiebungen, eisgestaute Seen und Rezession des Inlandeises in Estland. Fennia 52,2. Helsinki.

$\mathrm{R}$ a u k a s A. 1961. Mandrijää liikumisest Eestis. Eesti Loodus, 5.

S a u r a mo M. 1958. Die Geschichte der Ostsee. Suomalaisen Tiedeakatemian Toimituksia. Annales Academiae Scientiarum Fennicae. Sarja A. III. Geologica-Geographica, 51.

T a m mek a n A. 1928. Das Relief und die Abflussverhältnisse in Estland. 2. Baltische hydrologische und hydrometrische Konferenz. Tallinn, Juni 1928.

Thom s on P. 1939. Ulevaade Eesti soodest. Eesti Loodus, VII, 2/3.

Zur Mühlen L. 1918. Zur Geologie und Hydro'ogie des Wirzjärw-Sees. Abh. Preuss. geol. Landesanst, N. F., 83.

Ннститут геологии

Академии наук Эстонской ССР

Поступила в редакцию 12/XII 1968

\section{A. RAUKAS, E. RAHNI}

\section{PEIPSI-PIHKVA NŌO JA SEAL LEVINUD BASSEINIDE GEOLOOGILISEST ARENEMISEST}

Toetatakse seisukohta, et Peipsi-Pihkva nōgu on kujunenud preglatsiaalsel ajal, kusjuures hiijem on nōgu kujundanud vähemalt nelja mandrijäätumise liustikud. Nốo piires on vöimalik eristada viimase mandrijäätumise kahe staadiumi (faasi) - haanja (luuga) ja pandivere (neeva) - setteid ja pinnavorme ning rida liustiku servaasendeid. Taanduva haanja (luuga) staadiumi liustikuserva ees kujunes Pihkva nōos ja Peipsi nōo lōunaosas Pihkva jääpaisjärv (Urg-Pihkva K. Orviku, 1959 järgi), millel olid püsivamad veeseisud umbes $95,85,75,70,60,50$ ja $38 \mathrm{~m}$ juures üle merepinna. Veetasemeid $70 \mathrm{~m}$ juures ja körgemal seostatakse Pihkva I jääpaisjärve faasidega Pila, Pilb ja PiIc, tasemeıd alla $70 \mathrm{~m}$ - Pihkva II jääpaisjärve faasidega Pilla, Pillb ja PiIIc. Väljavool Pihkva I jääpaisjärvest toimus Vōru-Hargla vagumust mööda Koivasse (joon. 1-3), Pihkva II jääpaisjärvest peamiselt mööda Suur-Emajōe ürgorgu Urg-Võrtsjärve (Орвику, 1958) suunas (joon. 4,5 )

Taanduva pandivere (neeva) staadiumi jääkeele ees kujunes Peipsi jääpaisjärv (UrgPeipsi K. Orviku, 1959 järgi) väljavooluga läbi Urg-Võrtsjärve. Peipsi jääpaisjärve I faas (joon. 6) vastab ligikaudu H. Hauseni (1913) Lõuna-Peipsi jääpaisjärvele, II faas (joon. 7) - Luuga-Peipsi jääpaisjärvele (Ряхни, 1963а и др.), III faas (joon. 8) - K. Pärna (Пярна, 1962) jääpaisjärvele $A_{1}$ ja IV faas - K. Pärna jääpaisjärvele $A_{2}$.

Peale mandrijää serva taandumist Soome lahe piiridesse kujunes Peipsi nõos tõenäoliselt gotiglatsiaalse Joldiamere ja seejärel II Balti jääpaisjärve laht, kusjuures viimase regressiooni tähistavaid rannavorme on Peipsi nõo pōhjaosas võimalik jälgida viiel eri tasemel, mis paiknevad 50-37 m absoluutsel kōrgusel.

Maakoore neotektoonilise kerkimise tulemusena alanes hilisglatsiaali lōpus ja holotseeni alguses veetase sedavõrd, et järvenõo lōunaosa jäi kuivaks ja kujunenud Väike-Peipsi (Vana-Peipsi K. Orviku, 1959 järgi) hōlmas vaid järvenõo pōhjaosa (joon. 10).

Maakoore ebaühtlase (loodes suurem kui kagus) neotektoonilise kerkimise tõttu valgusid veed järgnevalt lõuna suunas (Hausen, 1913; K. Orviku, 1959), mille tagajärjel järve pind taas laienes ning pōhjavee tase tõusis. Viimane pōhjustas järvenõo kesk- ja !õunaosas intensiivse soostumise (Thomson, 19:9; Loopmann, 1964 jt.). Järvevete va.gumine lōunasse jätkub ka nüüdisajal. Kuna väljavool Peipsi järvest Narva jõe kaudu on raskendatud, tōuseb veetase ka Peipsi pōhjaosas. 


\section{A. RAUKAS, E. RÄHNI}

\section{ON THE GEOLOGICAL DEVELOPMENT OF THE PEIPSI-PIHKVA DEPRESSION AND THE BASINS DISTRIBUTED IN THAT REGION}

The authors are of the opinion that the Peipsi-Pihkva depression is of periglacial origin, with the glaciers of at least four continental glaciations participating in its formation. Within the borders of the depression it is possible to differentiate the two stages (phases) of the last continental glaciation - the Haanja (Luga) and Pandivere (Neva) deposits and relief forms, and a number of ancient glacier margins. In front of the retreating glacier of the Haanja (Luga) Stage, in the Pihkva depression and in the southern part of the Peipsi depression, the Pihkva Glacial Lake was formed (Ancient Pihkva, according to K. Orviku, 1959), whose most constant water levels were at 95,85 , $75,70,60,50$ and $38 \mathrm{~m}$ above sea level. The water levels at $70 \mathrm{~m}$ and higher were connected with the phases of the First Pihkva Glacial Lake (PiIa, PiIb and PiIc), and the water levels lower than $70 \mathrm{~m}$ - with the phases of the Second Pihkva Glacial Lake (PiIIa, PiIIb and PiIIc). The outflow from the First Pihkva Glacial Lake was effected by the Võru-Hargla hollow into the Koiva River (Figs 1-3), and from the Second Pihkva Glacial Lake - mainly via the old valley of Suur Emajōgi, in the direction of Ancient Vōrtsjärv Lake (Орвику, 1958; Figs 4, 5).

In front of the retreating glacier of the Pandivere (Neva) Stage, the Peipsi Glacial Lake (Ancient Peipsi, according to K. Orviku, 1959), with an outflow passing through Ancient Vōrtsjärv, was formed. The first phase of the Peipsi glacial Lake (Fig. 6) corresponds approximately to the South-Peipsi Glacial Lake by H. Hausen (1913), the second phase (Fig. 7) - to the Luga-Peipsi Glacial Lake (Ряхни, 1963a, and others), the third phase (Fig. 8) to the glacial lake $A_{1}$ by $K$. Pärna, and the fourth phase - to the $\mathrm{A}_{2}$ glacial lake by K. Pärna (Пярна, 1962).

After the retreat of the glacier into the Gulf of Finland, in the Peipsi depression, a bay of the Gothiglacial Yoldia Sea was developed and after that - a bay of the Second Baltic Glacial Lake; the relief forms marking the shore forms of the latter are still to be followed at five different levels in the northern part of the Peipsi depression, at the absolute height of $50-37 \mathrm{~m}$.

As a result of the neotectonic uplift of the Earth's crust at the end of the Late Glacial time and the beginning of the Holocene, the water level decreased to such an extent that the southern part of the lake dried up, and the Small Peipsi (Ancient Peipsi, according to K. Orviku, 1959) which was formed then occupied but the northern part of the depression (Fig. 10). Later on, owing to an unequal (in the NW more intensive than in the SE) neotectonic uplift. the waters flowed in the direction to the south (Hausen, 1913; K. Orviku, 1959), as a result of which the area of the lake was expanded once again, and the level of the subterranean water rose. The latter factor caused an intensive bogging-up of the central and southern parts of the depression (Thomson, 1939; Loopmann, 1964, et al.). The invasion of the lake water towards the South continues at the present time as well. Since the outflow from Lake Peipsi via the Narva River is not intensive, the water level is also rising in the northern part of the lake. 